\title{
E-banking Adoption in Romanian Companies: Determining Factors and Model
}

\author{
Liliana Mihaela Moga ${ }^{1}$, Khalil Md Nor ${ }^{2}$ and Eugen Mitrica ${ }^{3}$ \\ ${ }^{1}$ Dunarea de Jos University of Galati, Galati, Romania \\ ${ }^{2}$ Universiti Teknologi Malaysia, UTM Skudai, Malaysia \\ ${ }^{3}$ The Bucharest Academy of Economic Studies, Bucharest, Romania
}

\begin{abstract}
This paper investigates factors that influence Romanian companies to use Internet as a means to conduct their banking activities. The research model in this study was developed based on previous works that utilized technology acceptance theories and related empirical studies on the adoption of information technologies in economic activities, such as e-commerce and ebanking. Questionnaires were distributed to companies' managers in Romania. The data collected were subjected to factor analysis and multiple regression. The results show that compatibility, technical resources and self-efficacy have significant effect on the intention of the managers to use e-banking. Findings of this study indicate the importance of these three factors in influencing the Romanian companies to adopt e-banking. Addressing these factors in banks' marketing strategy may enhance their success to expand e-banking services to new corporate customers.
\end{abstract}

Keywords: e-banking, companies, influencing factors, technology acceptance.

\section{Introduction}

For a long time, there have been attempts to predict about Internet potential and how the number of users among individuals and companies could be increased. It is undeniable that in the last several years, the ubiquity of the Internet has radically changed the way certain services are delivered. The benefits offered by this new platform in accessing channels such as education, public services, commercial and financial without any direct contact with the service providers, have made elearning, e-government, e-commerce and ebanking increasingly very popular.

The changes induced by the Internet in conducting commercial transactions have already moved into a new stage, where the online service providers can customize their services to better satisfy their customer needs. The quality of e-services provided by these companies can help them to differentiate themselves from their competitors by offering services that enhance their customers' satisfaction, encourage repeated purchases and build higher loyalty (Zeithaml et al., 2002). Satisfaction can be defined as the emotional positive reaction to a product or service experience (Cristobal et al., 2007). Like any other organizations, banks have also made continuous efforts to improve their electronic services to fulfill their customers' needs in order to enhance their satisfactions of the services. As the banking needs differ between individuals and commercial customers, banks may need to take different strategies to introduce ebanking service exclusively for corporate customers. The new separate channel is worth investing as the opportunities brought by the Internet to serve corporate 
customers continue to arise (Alnsour and Al-Hyari, 2011).

A review of literature shows that most of the previous studies conducted in the domain of e-banking, especially its acceptance were mainly focused on individuals (Al-Somali et al., 2009; Cheng et al., 2006; Alsajjan and Dennis, 2010). Very few studies have explored e-banking acceptance by corporate customers. The fact that banks have already introduced online services tailored made exclusively to companies without extensive studies to understand corporate customers' intention to accept the services provide an opportunity of a study. Given the nature and needs of individuals and companies are different, the factors that influence them to accept e-banking may also differ. Therefore, the purpose of this study is to identify factors that influence Romanian companies' intention to use e-banking. The main constructs used in this study were derived from the theory of planned behavior (Ajzen, 1991), technology acceptance model (Davis, 1989), innovation diffusion theory (Rogers, 1983) and related findings from previous empirical studies focused on e-banking. The findings of this study can be an important input for banks to formulate marketing strategies, in their efforts to increase the adoption of e-banking among companies.

\section{Methodology}

As mentioned in the previous section, factors that influence the acceptance of ebanking among companies utilized in this study were derived from dominant technology acceptance theories. Selfefficacy and technical resources were derived from the decomposed theory of planned behavior (Taylor and Todd, 1995). The researchers borrowed the constructs of compatibility, complexity, trialability and observability from the theory of diffusion of innovation (Rogers, 1983), while perceived ease of use and perceived usefulness were adopted from the technology acceptance model (Davis, 1989). Security was selected based on the work of McKnight and Chervany (2001).
Based on previous empirical studies, the researchers added cost and accessibility. These factors were found to influence the adoption of e-banking (Erumban and Jong, 2006).

The relationships investigated in this study are as follows:

The higher the self-efficacy of the decision maker at the company has in using $e$ banking, the more likely the company will adopt the services.

The higher the availability of technical resources to use e-banking at the company such as computer and Internet, the more likely the company will adopt the services.

The higher the perceived compatibility of the e-banking services with the company values, the more likely the company will adopt the services.

The higher observability of e-banking services, the more likely the company will adopt the services.

The higher the perceived ease of use of the $e$ banking services, the more likely the company will adopt the services.

The higher the perceived usefulness the $e$ banking services, the more likely the company will adopt the services.

The lower the perceived cost of using $e$ banking services, the more likely the company will adopt the services.

The greater the accessibility of using $e$ banking services, the more likely the company will adopt the services.

All items used in this study to measure the study's constructs were adopted from previous studies. Four items were used to measure each construct. Measurement validity was checked using factor analysis. Based on this procedure, items that loaded highly on several factors were dropped. Furthermore, constructs were also dropped from further analysis if they were found to not be responding well with other constructs. Having ascertained the validity 
of the measurement instrument, multiple regression was run. The results of multiple regression, i.e., R-square shows the degree to which the variance of the intention to use e-banking is explained by all the constructs included as independent variables. The multiple regression also provides the coefficient and the significant level of the relationship between independent and dependent variable.

\section{Results}

A total of 92 questionnaires were distributed to target respondents. Out of 92 questionnaires distributed, 87 were usable for the analysis. Table 1 shows the respondents' demographic background.

Table 1: Demographic Profile

\begin{tabular}{|c|c|c|c|}
\hline Variable & Category & Frequency & $\%$ \\
\hline \multicolumn{4}{|l|}{ Place } \\
\hline & Capital & 12 & 13.8 \\
\hline & City & 8 & 9.2 \\
\hline & District & 64 & 73.6 \\
\hline & Rural & 3 & 3.4 \\
\hline \multicolumn{4}{|c|}{ Ownership } \\
\hline & State & 3 & 3.4 \\
\hline & Private & 83 & 95.4 \\
\hline & Mixed (State/Private) & 1 & 1.2 \\
\hline \multicolumn{4}{|c|}{ Business Type } \\
\hline & Public administration and defense & 2 & 2.3 \\
\hline & Commerce (include hotels and restaurants) & 15 & 17.2 \\
\hline & Transports, storage and communications & 5 & 5.8 \\
\hline & $\begin{array}{l}\text { Real estate transactions, Financial intermediations } \\
\text { and other services }\end{array}$ & 6 & 6.9 \\
\hline & Construction & 26 & 29.9 \\
\hline & Health and social assistance & 3 & 3.4 \\
\hline & Manufacturing & 21 & 24.1 \\
\hline & Agriculture, hunting, forestry and fishing & 4 & 4.6 \\
\hline & Other activities of the national economy & 5 & 5.8 \\
\hline \multicolumn{4}{|c|}{ - } \\
\hline & $<€ 2,000,000$ & 58 & 66.7 \\
\hline & $€ 2,000,001-€ 10,000,000$ & 20 & 23 \\
\hline & $€ 10,000,001-€ 50,000,000$ & 6 & 6.9 \\
\hline & $>€ 50,000,000$ & 1 & 1.1 \\
\hline & Not reported & 2 & 2.3 \\
\hline \multicolumn{4}{|l|}{ Position } \\
\hline & General Manager & 29 & 33.3 \\
\hline & Financial Manager & 38 & 43.7 \\
\hline & Assistant Manager & 20 & 23.0 \\
\hline \multicolumn{4}{|c|}{ thes 0} \\
\hline & $<30$ years old & 6 & 6.9 \\
\hline & 30 to 40 years old & 36 & 41.4 \\
\hline & 41-55 years old & 37 & 42.5 \\
\hline & Over 55 years old & 8 & 9.2 \\
\hline
\end{tabular}

A Cronbach alpha was performed to check on the reliability of the construct measurements. Only the reliability of seven constructs is presented here. Two constructs, which will be explained later in the next paragraph, were dropped from this study, as they did not discriminate well with other constructs. Table 2 below shows the Cronbach alpha for each construct. They were all above 0.6, ranging from 0.814 to 0.972 , which suggest measurements used in this study were reliable (Hair et al., 1998). 
Table 2: Reliability Results

\begin{tabular}{|l|c|c|}
\hline Construct & No. of Items & Cronbach's Alpha \\
\hline Perceived usefulness & 3 & 0.814 \\
\hline Compatibility & 4 & 0.960 \\
\hline Self-efficacy & 3 & 0.914 \\
\hline Technical resources & 3 & 0.897 \\
\hline Accessibility & 4 & 0.949 \\
\hline Observability & 2 & 0.946 \\
\hline Intention & 4 & 0.972 \\
\hline
\end{tabular}

Validity of the constructs was evaluated by performing factor analysis. Table 3 shows the final output of the factor analysis using principal components with varimax rotation. Originally, this study had proposed eight factors that influence the intention to use e-banking by Romanian companies. Based on the factor analysis, however, two constructs were dropped, namely cost and perceived ease of use. The analysis showed that all items used to measure these constructs were loaded on many factors. The constructs did not discriminate well. It was decided to drop the constructs from the analysis.

Furthermore, several items measuring the constructs in this study were also dropped. One item was dropped from each of these constructs i.e., perceived usefulness, selfefficacy and technical resources and two items were dropped from the observability construct. The items were dropped as they loaded highly on other constructs.

Table 3: Rotated Component Matrix

\begin{tabular}{|c|c|c|c|c|c|c|c|c|}
\hline Items & F1 & F2 & F3 & F4 & F5 & F6 & F7 & F8 \\
\hline Perceived usefulness 1 & 0.749 & & & & & & & \\
\hline Perceived usefulness 3 & 0.787 & & & & & & & \\
\hline Perceived usefulness 4 & 0.736 & & & & & & & \\
\hline Compatibility1 & & 0.851 & & & & & & \\
\hline Compatibility2 & & 0.917 & & & & & & \\
\hline Compatibility3 & & 0.907 & & & & & & \\
\hline Compatibility4 & & 0.881 & & & & & & \\
\hline Self-efficacy 2 & & & & 0.862 & & & & \\
\hline Self-efficacy 3 & & & & 0.892 & & & & \\
\hline Self-efficacy 4 & & & & 0.842 & & & & \\
\hline Technical resources 1 & & & & & 0.815 & & & \\
\hline Technical resources 2 & & & & & 0.846 & & & \\
\hline Technical resources 4 & & & & & 0.863 & & & \\
\hline Accessibility1 & & & & & & 0.926 & & \\
\hline Accessibility2 & & & & & & 0.942 & & \\
\hline Accessibility3 & & & & & & 0.930 & & \\
\hline Accessibility4 & & & & & & 0.824 & & \\
\hline Observability1 & & & & & & & 0.942 & \\
\hline Observability 2 & & & & & & & 0.971 & \\
\hline
\end{tabular}

Notes: Only loading > 0.4 are shown; Extraction Method: Principal Component Analysis;

Rotation Method: Varimax with Kaiser Normalization; Rotation converged in 7 iterations.

Table 4 shows the results of multiple regression analysis. Before the results were interpreted, the researchers analyzed the variance inflation factor (VIF). VIF that is greater than 10 indicates the presence of multicollinearity (Cooper and Schindler, 2003). From the table below, VIF shows values ranging from 1.107 to 1.752 , indicating a low threat of multicolinearity. The results of the multiple regressions 
show that out of the six factors to influence the intention to use e-banking, three factors were found significant. They are compatibility, self-efficacy and technical resources. The three factors that were found not significant are perceived as usefulness, accessibility and observability. Overall, the six factors explain $82.1 \%$ of the variance.

\section{Table 4: Regression Results}

\begin{tabular}{|c|c|c|c|c|}
\hline \multicolumn{5}{|c|}{$\begin{array}{l}\text { Multiple } R=0.906 \\
R \text { squared }=0.821 \\
\text { Adjusted } R \text { squared }=0.808 \\
\text { Standard error }=0.39035\end{array}$} \\
\hline Variable & Beta & $t$ & Sig. & VIF \\
\hline Perceived usefulness & 0.001 & -0.003 & 0.998 & 1.752 \\
\hline Compatibility & 0.740 & 12.597 & 0.000 & 1.547 \\
\hline Self-efficacy & 0.121 & 2.077 & 0.041 & 1.521 \\
\hline Technical resources & 0.194 & 3.351 & 0.001 & 1.505 \\
\hline Accessibility & -0.086 & -1.587 & 0.116 & 1.322 \\
\hline Observability & 0.086 & 1.733 & 0.087 & 1.107 \\
\hline
\end{tabular}

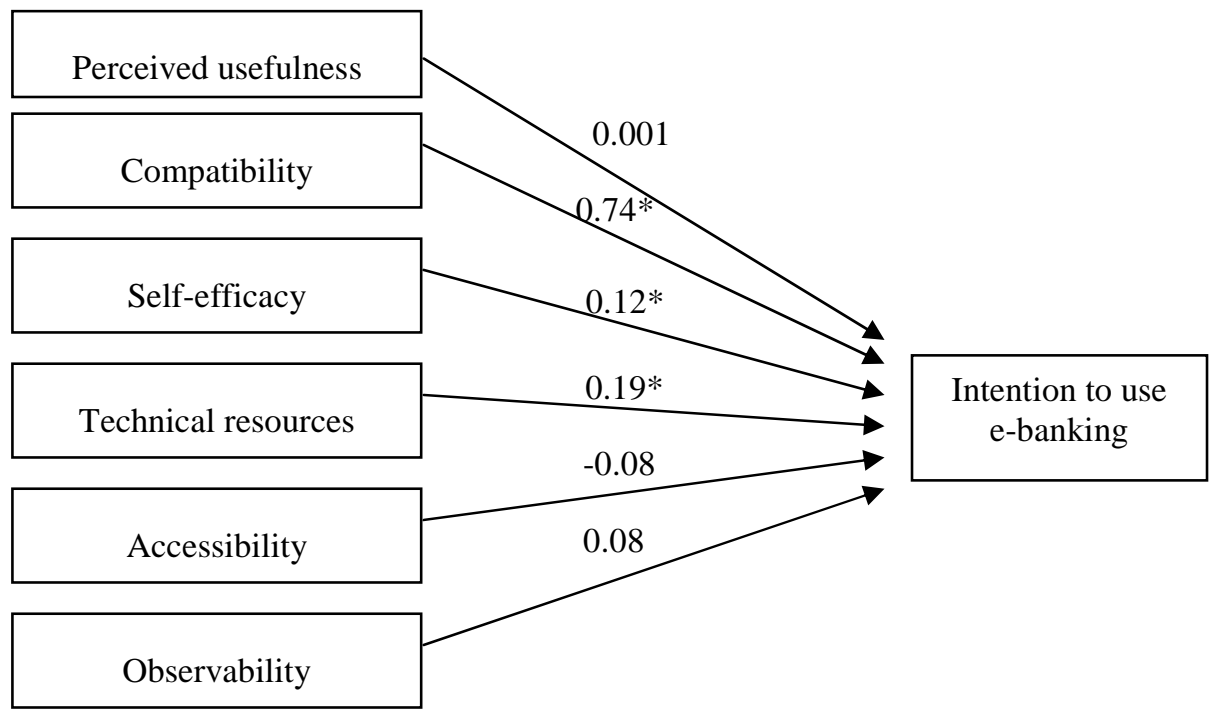

Note: * Significant at 0.05

Figure 1: Final Model

\section{Discussions}

From the analysis, 95.4\%, 3.4\% and 1.2\% of the respondents were from private, state and mixed owned companies respectively. In terms of location, $96.6 \%$ of the companies were located in the urban area, and $3.4 \%$ were located in the rural area. Overall, most of the surveyed companies were located in large towns. In general, more than 70 percent of the companies surveyed were in construction, manufacturing and commerce sectors. This interestingly reflects the general structure of the Romanian economy. Most of the companies had turnover of less than EUR $2,000,000$. Twenty three percent of the companies made turnover of between EUR $2,000,001$ and 10,000,000.

The respondents were key managers of the companies who the researchers felt are able to provide good evaluation on factors that may influence his or her company to adopt e-banking services as an alternative means to the traditional banking. In terms 
of their position, $33.3 \%$ were General Managers, 43.7\% were Financial Managers and $23.0 \%$ were Assistant Managers. Forty two percent of the respondents were more than 40 years old, while $41.4 \%$ were between 30 and 40 years old.

Overall, all the factors tested in this study explain 82.1 percent of the variance in the intention to use e-banking. Multiple regressions results show that there are three factors that influence Romanian companies to use e-banking. The factors were compatibility, self-efficacy and availability of technical resources. Based on the multiple regressions coefficient, compatibility was found to be the most influencing factor. An innovation or a new technology introduced to the market can result in a slight or major change in the way the adopters normally perform a task. The probability of the innovation to be adopted is higher when the innovation is more or less conformed to the lifestyle of the adopters (Rogers, 1983). An innovation that results in major disruptions of the adopters' lifestyle has lower chance to be adopted. In the case of e-banking, it has features that fit well with the current ways of performing banking transactions. Therefore, the finding of this study that put compatibility as the main influencing factor on the intention to use e-banking was expected. The second influencing factor was the availability of technical resources. Performing e-banking requires Internet connection and computer. Without these technical resources, the ability to perform e-banking transactions is hindered. The findings of the study suggest the importance of having adequate and proper technical resources by banking users before they use the e-banking. Providing these resources is not a major problem for most of the companies. Due to limited financial resources, it is probably restricted to small companies. The third factor that significantly affects the intention to use ebanking is self-efficacy. This factor reflects the confidence of the companies to use the new technology. It refers to the internal psychological abilities of the users to perform the e-banking. Self-efficacy may be affected by the users' perception of the external features of the technology such as the ease of use. Enhancing the selfconfidence of the users requires concentrated efforts by banks. Systems wise, banks need to ensure e-banking is easy to use. This may include designing a simple interface that does not require high mental efforts of the users. In addition, banks may want to use advertising that project the messages of simplicity in performing e-banking.

The results of the study have also shown that the other three factors; namely, perceived usefulness, accessibility and oberservability did not have significant effect on the intention to use e-banking among companies in Romania. The results are surprising given the facts that these factors were found to be significant in previous studies. A possible explanation to the insignificant relationship is that the respondents may equate e-banking with the traditional banking in performing financial transactions; hence, playing down its usefulness. They may feel that it does not matter whether the transactions are performed online or off-line as long as the transactions are done. On the observability relationship to the intention, the insignificant relationship may be influenced by the nature of this technology. Unlike other product technologies where individuals are able to observe and see the technology being used, e-banking transactions are performed in private. This may affect the perception of the respondents in evaluating the degree of influence of this construct on the intention. Finally, the negative relationship of accessibility with the intention was surprising. However, the results show that the coefficient is small and the relationship is insignificant.

\section{Conclusions}

As highlighted in the discussion section, this study has found three factors that influence the intention of Romanian companies to use e-banking. They are compatibility, self-efficacy and availability of technical resources. Taking into account these factors and addressing them in their marketing strategies, banks may be able to reduce the disinclination of Romanian 
companies' intention to adopt e-banking in managing their financial transactions. Suggestions provided in the discussion section may assist banks to take practical actions in inspiring companies to use ebanking.

\section{Acknowledgements}

This work is supported by CNCS UEFISCDI, project number: PNII - IDEI 1852/2008, contract number: 957/2009.

\section{References}

Ajzen, I. (1991). "The Theory of Planned Behavior," Organizational Behavior and Human Decision Processes, 50, 179-211.

Al-Somali, S. A., Gholami, R. \& Clegg, B. T. (2009). "An Investigation into the Acceptance of Online Banking in Saudi Arabia," Technovation, 29(2), 130-141.

Alnsour, M. S. \& Al-Hyari, K. (2011). "Internet Banking and Jordanian Corporate Customers: Issues of Security and Trust," Journal of Internet Banking and Commerce, 16(1), 1-14.

Alsajjan, B. \& Dennis, C. (2010). "Internet Banking Acceptance Model: Cross-Market Examination," Journal of Business Research, 63(9-10), 957-963.

Cheng, T. C., Lam, D. Y. C. \& Yeung, A. C. L. (2006). "Adoption of Internet Banking: An Empirical Study in Hong Kong," Decision Support Systems, 42, 1558-1572.

Cooper, D. R. \& Schindler, P. S. (2003). Business Research Methods, 8th Edition, New York, NY, McGraw-Hill.

Cristobal, E., Flavian, C. \& Guinaliu, M. (2007). "Perceived E-Service Quality: Measurement Validation and Effects on Consumer Satisfaction and Website Loyalty," Managing Service Quality, 17(3), 317-340.
Davis, F. D. (1989). "Perceived Usefulness, Perceived Ease of Use, and User Acceptance of Information Technology," MIS Quarterly 13(3), 319-340.

Erumban, A. A. \& Jong, S. B. (2006). "CrossCountry Differences in ICT Adoption: A Consequence of Culture?," Journal of World Business, 41, 302-314.

Hair, J. F. Jr., Anderson, R. E., Tatham, R. L. \& Black, W. C. (1998). Multivariate Data Analysis. Upper Saddle River, NJ, PrenticeHall.

McKnight, D. H. \& Chervany, N. L. (2001). "What Trust Means in E-Commerce Customer Relationships: An Interdisciplinary Conceptual Typology," International Journal of Electronic Commerce, 6(2), 35-59.

Rogers, E. M. (1983). The Diffusion of Innovations. Free Press, New York, Free Press.

Taylor, S. \& Todd, P. A. (1995). "Understanding Information Technology Usage: A Test of Competing Models," Information Systems Research, 6(2), 144176.

Zeithaml, V. A., Parasuraman, A. \& Malhotra, A. (2002). "Service Quality Delivery through Websites: A Critical Review of Extant Knowledge," Journal of the Academy of Marketing Science, 30(4), 362-375. 